\title{
POPULATION PHARMACOKINETICS OF VANCOMYCIN IN ADULT PATIENTS WITH LONG BONES' FRACTURES
}

Jasmina Milovanovic ${ }^{1}$ Radica Zivkovic Zaric ${ }^{1 *}$, Nikola Rosic ${ }^{2}$, Dejana Ruzic Zecevic ${ }^{1}$, Dragan Milovanovic ${ }^{1}$, Marko Folic ${ }^{1}$ and Slobodan M. Jankovic ${ }^{1}$ ${ }^{1}$ University of Kragujevac, Faculty of Medical Sciences, Department of Pharmacology and Toxicology, Kragujevac, Serbia ${ }^{2}$ Department of Clinical Pharmacology, Clinical Center Kragujevac, Serbia

\section{POPULACIONA FARMAKOKINETIKA VANKOMICINA KOD ODRASLIH PACIJENATA SA PRELOMIMA DUGIH KOSTIJU}

Jasmina Milovanovic ${ }^{1}$, Radica Živković Zarić1*, Nikola Rosić ${ }^{2}$, Dejana Ružić Zečević1, Dragan Milovanović1 ${ }^{1}$, Marko Folić ${ }^{1}$ i Slobodan M. Janković

${ }^{1}$ Univerzitet u Kragujevcu, Fakultet medicinskih nauka, Katedra za farmakologiju i toksikologiju, Kragujevac, Srbija

${ }^{2}$ Služba za klinicku farmakologiju, Klinički centar Kragujevac, Srbija

\section{ABSTRACT}

Vancomycin is a tricyclic glycopeptide antibiotic, mostly used in the treatment of severe staphylococcal and enterococcal infections, especially in orthopedic surgery.

The purpose of this analysis was to develop a population pharmacokinetic (PPK) model of vancomycine in hospitalized patients with bone fractures and identify important factors which influence its clearance (CL).

A total of ninety-nine measurements of vancomycin serum concentrations were used in our population modeling. A twocompartment model was applied to describe the pharmacokinetics of vancomycin using subroutines ADVAN3 and TRANS4.

The study population included patients of both sexes, with the mean age of $62.12 \pm 14.69$ years and body weight of $80.32 \pm 12.44 \mathrm{~kg}$. Vancomycin was administered as intravenous infusion with average daily dose of $1772.73 \pm 521.34 \mathrm{mg}$. Out of twenty different factors evaluated in the study (including demographic, clinical and laboratory data), only daily dose of vancomycin (DD) and co-medication with piperacillin/tazobactam (PT) showed significant effect on clearance of vancomycin. The final model was described by the following equation: $C L(l / h)=0.03$ $+0.000468 \times D D+0.675 \times$ PT. Bootstrapping was used for validation of the final model.

In conclusion, the main causes of variability in the clearance of vancomycin among adult patients with bone fractures are daily dose of vancomycin and co-medication with piperacillin/tazobactam.

Keywords: vancomycin, population pharmacokinetics, trauma, non-linear mixed effects model (NONMEM).

\section{SAŽETAK}

Vankomicin je triciklicni glikopeptidni antibiotik, koji se koristi u terapiji teških infekcija izazvanih stafilokokom i enterokokom, posebno u ortopedskoj hirurgiji.

Svrha ovog istraživanja bila je da se razvije populacioni farmakokinetski (PPF) model vankomicina kod hospitalizovanih pacijenata sa prelomima dugih kostiju i da se utvrde faktori koji su bitni za klirens $(K L)$ vankomicina.

Devedest devet uzoraka seruma sa izmerenim koncentracijama vankomicina je korišćeno za naš model. Model sa dva prostora je korišćen da opiše farmakokinetiku vankomicina sa potprogramima ADVAN3 i TRANS4.

Populacija je uključivala oba pola, sa prosečnom starošću $62,12 \pm 14,69$ godina i telesnom težinom $80,32 \pm 12,44 \mathrm{~kg}$. Vankomicin je primenjivan u obliku intravenske infuzije sa prosečnom

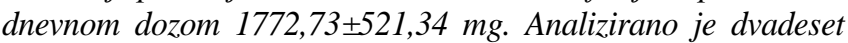
faktora, a utvrđeno je da samo dnevna doza vankomicina i primena piperacilin tazobaktama značajno utiču na klirens vankomicina. Završni model je opisan jednačinom: $K L(l / h)=0.03+$ $0.000468 \times D D+0.675 \times P T$. Butstrap analiza je korišćena za validaciju krajnjeg modela.

Uzaključku, glavni uzroci varijabilnosti klirensa vankomicina među odraslim pacijentima sa prelomima dugih kostiju jesu dnevna doza vankomicina i komedikacija piperacilin tazobaktamom.

Ključne reči: vankomicin, populaciona farmakokinetika, trauma, NONMEM.

\section{ABBREVIATIONS}

acute kidney injury (AKI)

alanine aminotransferase (ALT)

angiotensin-converting enzyme (ACE) inhibitors

aspartate aminotransferase (AST)

clearance (CL)

coefficient of variation $(\mathrm{CV})$

colistin (COL)

C-reactive protein (CRP)

fibrinogen (FB)

first-order conditional estimation (FOCE) furosemide (FUR)

heparin (HEP)

minimum objective function (MOF)

non-linear mixed effects model (NONMEM)

nonsteroidal anti-inflammatory drugs (NSAIDs)

piperacillin/tazobactam (PT)

population pharmacokinetics (PPK)

population predicted (PRED)

pro-brain natriuretic peptide (proBNP)

therapeutic drug monitoring (TDM)

\section{sciendo}

UDK: 615.33.03

616-089.23-022.3

616.71-001.5-089.23

Ser J Exp Clin Res 2021; 22 (3): 233-240

DOI: 10.247 8/sjecr-2019-0025
Corresponding author: Radica Živkovic Zarić, MD, PhD ciences, University of Kragujevac 69 Svetozara Markovica Street 34000 Kragujevac, Serbia radica_zivkovic@yahoo.com 


\section{INTRODUCTION}

Vancomycin is a tricyclic glycopeptide antibiotic, first isolated in 1956, mostly used for the treatment of severe staphylococcal and enterococcal infections. The mechanism of action of vancomycin is by inhibiting peptidoglycan fusion within the cell wall by binding alanine (1). Increased incidence of meticillin resistant staphylococcal strains led to more extensive use of vancomycin in various patient populations (2).

Regardless of its hydrophilicity, vancomycin is extensively distributed, as its volume of distribution ranges between 0.4 and $1 \mathrm{l} / \mathrm{kg}$ of the total body weight. About $55 \%$ of drug in plasma is bound to human serum proteins, mostly to albumin and IgA. Following intravenous administration, vancomycin is minimally metabolized and renal elimination accounts for $80-90 \%$ of vancomycin clearance (3-5). Vancomycin pharmacokinetics has been described by one-, two-, or three-compartment models (2-4).The elimination half-life ranges from 3 to 9 hours in patients with normal renal function. Data suggest that maintaining vancomycin trough values above $15 \mathrm{mg} / \mathrm{l}$ increases the risk of nephrotoxicity, but low concentrations may result in less effective therapy and an increased bacterial resistance. On the other hand, it was reported that dosing regimens with $4 \mathrm{~g}$ of vancomycin per day had been related with a high rate of nephrotoxicity or ototoxicity $(6,7)$. All of these facts created a need to more carefully inspect the factors that influence variability of vancomycin pharmacokinetics (2).

Different patients' conditions such as renal function, type of dialysis or presence of various diseases could influence vancomycin pharmacokinetics (8). Only a few population pharmacokinetic studies of vancomycin were performed in specific subgroups of patients, like neonates, pediatric patients, obese patients and neurosurgical patients among others, and no reports on vancomycin pharmacokinetics in patients with bone fractures were previously published (3, 9$11)$.

\section{THE AIM OF THE PAPER}

The aim of our study was to calculate average values of serum vancomycin concentrations and determine factors that may affect them in adult patients hospitalized due to long bones' fracture.

\section{METHODS}

\section{Patient data}

Target population consisted of 99 inpatients with long bones' fractures, hospitalized in Clinical Center (Kragujevac, Serbia), where vancomycin was administered as an intravenous infusion. Serum samples were prospectively collected using routine therapeutic drug monitoring (TDM) from January to September 2017. The study protocol was approved by the Ethics Committee of the Clinical Center Kragujevac $\left(\mathrm{N}_{0}\right.$ 01-1267, approved on February $1^{\text {st }} 2016$ ) and informed written consent was obtained from all the participants enrolled. Also, the research was conducted in accordance with the principles of the Helsinki Declaration.

The data were collected from medical documentation and included records related to patient demographic characteristics (body weight, age and sex), value of laboratory tests (creatinine clearance, serum albumin, total bilirubin, aspartate aminotransferase (AST), alanine aminotransferase (ALT), Creactive protein (CRP), fibrinogen (FB), pro-brain natriuretic peptide (proBNP)) and clinical data (length of hospitalization, presence of sepsis and concomitant medications). All variables are summarized in Table 1 . The inclusion criteria were: adult patients (>18 years old) hospitalized due to fracture(s) of long bones and an intravenous administration of vancomycin for at least 3 days without changes in the daily dose. Patients on dialysis, with history of cirrhosis and various types of cancer were excluded. Serum concentrations of vancomycin were measured by immunoassay using Cobas $^{\circledR} \mathrm{e}$ 601 analyzer (Roche Diagnostics, Mannheim, Germany), according to the manufacturer's instructions. To ensure that the drug concentrations were at steady-state, all samples were obtained after $72 \mathrm{~h}$ hours of repeated doses of vancomycin. The trough serum concentrations were the most often recorded (from seventy-eight patients), while only 21 blood samples were taken 1-3h after administration of the drug.

\section{Population pharmacokinetics analysis}

Pooled data were available from all patients and analyzed using the NONMEM software version 7.3.0 (Icon Development Solution, MD,) with FOCE (first-order conditional estimation) approach with interaction between parameters included in our population pharmacokinetics (PPK) modeling $(12,13)$. We evaluated two structural models (one-compartment and two-compartment) in accordance with the literature data related to vancomycin pharmacokinetics. The base model was selected according to the size of the minimum objective function (defined as -2 timed the log-likelihood MOF) and by the insight into diagnostic plots. Subroutines ADVAN3 and TRANS4 were utilized in a two-compartment model to describe pharmacokinetics of vancomycin and its clearance as the main parameter. Normal distribution of the individual pharmacokinetic parameters was assumed by our model. At this phase of the study, we also investigated various models of error to account for both inter-individual and residual variability. The inter-individual variability was tested using additive and exponential error models, while residual variability was tested using an additive, exponential, constant coefficient of variation (CCV) and combined (additive and (CV) error models.

The following demographic, clinical and laboratory test data were collected for evaluation as potential covariates: total body weight (TBW), age and sex of patients, length of hospitalization, presence of sepsis, total daily dose of vancomycin, creatinine clearance, serum albumin, total bilirubin, AST, ALT, CRP, fibrinogen, proBNP and co-medication with colistin (COL), furosemide (FUR), piperacillin/ 
tazobactam (PT), nonsteroidal anti-inflammatory drugs (NSAIDs), heparin (HEP) and angiotensin-converting enzyme (ACE) inhibitors. All continuous variables examined in the study were not parameterized. The covariate model was built in stepwise manner where each covariate was added one at a time using linear or nonlinear manner. To compare individual covariate models, we used change in the MOF values and the visual inspection of plots in order to estimate better fitting of data relative to the base model. The reduction in the MOF produced by inclusion of a covariate for at least 3.84 $(p<0.05$, d.f. $=1)$ and also the improvements of the fitting data were the main criteria for inclusion of covariate in the full model. The full model was created by insertion of all significant covariates at the same time. This model was further tested by the backward deletion process for each covariate, one at a time, to obtain the final model. An increase in the MOF of at least $6.64(p<0.01$, d.f. $=1)$ was used as the main criteria for retaining significant covariate in the final model. During all levels in the building of the final PPK model for vancomycin clearance, we evaluated presence of the reduction in both mentioned variability and also the improvements in diagnostic plot of the observed concentrations versus population predicted concentrations of vancomycin.

In order to validate the derived PPK model and estimate its predictive performance, we applied the bootstrapping analysis. This non-parametric method is a resembling technique that includes large number of data replicates (several hundred or thousand) with replacement from the index set using the individual patients as the sampling unit. Each of the bootstrap data sets was fitted to the final model to obtain the bootstrap estimated values of pharmacokinetic parameters and their variability was tested using NONMEM software. The mean values of estimated PK parameters and 2.5th97.5th percentile of the bootstrap data set parameters were compared to the final pharmacokinetic parameter estimates.

\section{RESULTS}

A total of ninety-nine vancomycin serum concentrations from adult inpatients with long bone fractures were included in our population modeling. A two-compartment model was applied to describe the pharmacokinetics of vancomycin. Our results have shown that an exponential model was the best model that described the inter-individual variability, while the residual error was incorporated as an additive error model. The study population included patients of both sexes with a wide age range from 20 to 86 years. The mean value of body weight was $80.32 \pm 12.44 \mathrm{~kg}$, and it ranged from 60 to $110 \mathrm{~kg}$. The drug was usually administered twice a day as intravenous infusion with an average daily dose of $1770 \mathrm{mg}$ (500-3000 mg). Furthermore, our population was very heterogeneous in terms of renal function and included patients with both normal $(\mathrm{n}=44)$ and impaired renal function $(n=55)$. The clearance of creatinine varied from 30 to 252 $\mathrm{ml} / \mathrm{min}$, with a mean value of $93.22 \pm 51.05 \mathrm{ml} / \mathrm{min}$. Patient characteristics are summarized in Table 1. Estimates of vancomycin pharmacokinetic parameters in the target population were $0.922 \mathrm{l} / \mathrm{h}$ and $11.1 \mathrm{l}$ for the population value of clearance and the volume of distribution, respectively. The MOF value in this stage was 1103.714 units and both inter-individual and residual variability for clearance of vancomycin were $57.43 \%$ and $48.47 \%$ expressed as coefficient of variation (CV), respectively.

As a result of the univariate model analyses, a total of seven covariates (daily dose, creatinine clearance, AST, CRP and co-medication with furosemid, piperacillin/tazobactam and NSAIDs) produced significant decreases in MOF values and were detected as influential covariates in the full model. These data are shown in Table 2. Using backward deletion process, only two covariates (daily dose of vancomycin and co-medication with piperacillin/tazobactam) were retained in the final PPK model. Derived population pharmacokinetics model which describes the clearance of vancomycin in the target population is:

$$
\mathrm{CL}(\mathrm{l} / \mathrm{h})=0.03+0.000468 \times \mathrm{DD}+0.675 \times \mathrm{PT}
$$

where 0.03 is a typical population value of clearance, while 0.000468 and 0.675 are magnitudes of effect of vancomycin daily dose and co-medication with piperacillin/tazobactam, respectively.

The goodness-of-fit plots indicate a good fit of the data from the final regression model. Population predicted (PRED) values of vancomycin concentrations versus its observed concentrations (DV) in the base model and the final model are shown in Figure 1. Compared to the base model, there is a reduction in coefficients of variation by $19.56 \%$ and $16.55 \%$ for inter-individual and residual variability, respectively.

Two hundred bootstrap runs were included in the bootstrap analysis. Table 3 shows the summary of parameter estimates and their 95\% confidence intervals for the final PPK model obtained by the bootstrap analysis. Furthermore, the mean values of parameter estimates using bootstrap were comparable with the values obtained from original NONMEM analysis, indicating that the estimates of the population PK parameters in the final model were accurate and the model was stable. 
Table1. Demographic characteristics of the patients, laboratory and clinical data.

\begin{tabular}{|l|c|c|}
\hline \multicolumn{1}{|c|}{ Characteristics } & $\begin{array}{c}\text { Index set } \\
\text { (mean values } \pm \text { standard deviation) }\end{array}$ & $\begin{array}{c}\text { Range for } \\
\text { index set }\end{array}$ \\
\hline Number of patients & 99 & \\
\hline Number of observations & 99 & \\
\hline Gender (male/female) & $60 / 39$ & $20-86$ \\
\hline Total body weight (kg) & $80.32 \pm 12.44$ & $500-3000$ \\
\hline Age (years) & $62.12 \pm 14.69$ & $1-90$ \\
\hline Vancomycin dose (mg/day) & $1772.73 \pm 521.34$ & $30-252$ \\
\hline Length of hospitalization (day) & $16.06 \pm 14.76$ & $13-40$ \\
\hline Creatinine clearance (ml/min) & $93.23 \pm 51.05$ & $4.4-493.5$ \\
\hline Serum albumin (g/l) & $26.71 \pm 3.45$ & $9-448$ \\
\hline Total bilirubin ( $\boldsymbol{\mu g} / \mathbf{l})$ & $12.98 \pm 49.12$ & $4-436$ \\
\hline AST concentration (IU/l) & $37.76 \pm 46.59$ & $1.04-303$ \\
\hline ALT concentration (IU/l) & $30.86 \pm 52.76$ & $1.81-8.17$ \\
\hline C-reactive protein (mg/l) & $96.57 \pm 79.83$ & $200-22311$ \\
\hline Fibrinogen (g/l) & $3.49 \pm 1.27$ & \\
\hline proBNP (pg/ml) & $688.29 \pm 2371.07$ & \\
\hline Presence of sepsis (yes/no) & $8 / 91$ & \\
\hline Vancomycin + comedication with: & 10 & \\
\hline Colistin & 23 & \\
\hline Furosemide & 7 & \\
\hline Piperacillin/tazobactam & 23 & \\
\hline NSAIDs & 15 & \\
\hline ACE inhibitors & & \\
\hline
\end{tabular}

Table2. Values of minimum objective function for univariate regression models of examined covariates in the process of building a full pharmacokinetic model for vancomycin clearance.

\begin{tabular}{|l|c|c|}
\hline \multicolumn{1}{|c|}{ Clearance models } & $\begin{array}{c}\text { Minimum objective function } \\
\text { (MOF) }\end{array}$ & p-value $^{* *}$ \\
\hline BASE MODEL & & \\
\hline $\mathrm{CL}=\theta_{1} \times \mathrm{EXP}(\mathrm{ETA}(1))$ & & $>0.05$ \\
\hline REGRESSION MODELS & & $>0.05$ \\
\hline $\mathrm{CL}=\theta_{1} \times \mathrm{EXP}(\mathrm{ETA}(1))+\theta_{3} \times \mathrm{TBW}$ & 446.478 & $>0.05$ \\
\hline $\mathrm{CL}=\theta_{1} \times \mathrm{EXP}(\mathrm{ETA}(1))+\theta_{4} \times \mathrm{AGE}$ & 0.005 & $<0.05$ \\
\hline $\mathrm{CL}=\theta_{1} \times \mathrm{EXP}(\mathrm{ETA}(1))+\theta_{5} \times \mathrm{SEX}$ & 84.698 & $<0.05$ \\
\hline $\mathrm{CL}=\theta_{1} \times \mathrm{EXP}(\mathrm{ETA}(1))+\theta_{6} \times \mathrm{DD}$ & 34.03 & $>0.05$ \\
\hline $\mathrm{CL}=\theta_{1} \times \mathrm{EXP}(\mathrm{ETA}(1))+\theta_{7} \times \mathrm{CLCr}$ & 0.102 & $>0.05$ \\
\hline $\mathrm{CL}=\theta_{1} \times \mathrm{EXP}(\mathrm{ETA}(1))+\theta_{8} \times \mathrm{LP}$ & 0.415 & $>0.05$ \\
\hline $\mathrm{CL}=\theta_{1} \times \mathrm{EXP}(\mathrm{ETA}(1))+\theta_{9} \times \mathrm{ALB}$ & 0.308 & $<0.05$ \\
\hline $\mathrm{CL}=\theta_{1} \times \mathrm{EXP}(\mathrm{ETA}(1))+\theta_{10} \times \mathrm{BIL}$ & 25.186 & \\
\hline $\mathrm{CL}=\theta_{1} \times \mathrm{EXP}(\mathrm{ETA}(1))+\theta_{11} \times \mathrm{AST}$ & & \\
\hline
\end{tabular}




\begin{tabular}{|c|c|c|}
\hline Clearance models & $\begin{array}{l}\text { Minimum objective function } \\
\text { (MOF) }\end{array}$ & p-value ** \\
\hline $\mathrm{CL}=\theta_{1} \times \mathrm{EXP}(\operatorname{ETA}(1))+\theta_{12} \times \mathrm{ALT}$ & 0.923 & $>0.05$ \\
\hline$C L=\theta_{1} \times \operatorname{EXP}(\operatorname{ETA}(1))+\theta_{13} \times \mathrm{CRP}$ & 5.054 & $<0.05$ \\
\hline $\mathrm{CL}=\theta_{1} \times \mathrm{EXP}(\mathrm{ETA}(1))+\theta_{14} \times \mathrm{FIB}$ & 0.740 & $>0.05$ \\
\hline $\mathrm{CL}=\theta_{1} \times \mathrm{EXP}(\mathrm{ETA}(1))+\theta_{15} \times$ proBNP & 0.602 & $>0.05$ \\
\hline $\mathrm{CL}=\theta_{1} \times \mathrm{EXP}(\operatorname{ETA}(1))+\theta_{16} \times \mathrm{SEP}$ & 0.533 & $>0.05$ \\
\hline $\mathrm{CL}=\theta_{1} \times \mathrm{EXP}(\mathrm{ETA}(1))+\theta_{17} \times \mathrm{COL}$ & 3.245 & $>0.05$ \\
\hline $\mathrm{CL}=\theta_{1} \mathrm{x} \operatorname{EXP}(\operatorname{ETA}(1))+\theta_{18} \times \mathrm{FUR}$ & 3.95 & $<0.05$ \\
\hline $\mathrm{CL}=\theta_{1} \mathrm{x} \operatorname{EXP}(\operatorname{ETA}(1))+\theta_{18} \mathrm{X}$ TAZ & 23.277 & $<0.05$ \\
\hline $\mathrm{CL}=\theta_{1} \mathrm{x} \operatorname{EXP}(\mathrm{ETA}(1))+\theta_{19} \mathrm{x}$ NSAIDs & 15.628 & $<0.05$ \\
\hline $\mathrm{CL}=\theta_{1} \mathrm{x} \operatorname{EXP}(\operatorname{ETA}(1))+\theta_{20} \mathrm{x}$ HEP & 0.068 & $>0.05$ \\
\hline $\mathrm{CL}=\theta_{1} \times \mathrm{EXP}(\mathrm{ETA}(1))+\theta_{21} \times \mathrm{ACE}$ & 0.612 & $>0.05$ \\
\hline
\end{tabular}

CL, clearance (1/h); $\theta_{1}$,typical value of CL; ETA(1), interindividual variability in CL; ${ }^{\mathrm{d}} \theta_{3}$ to $\theta_{21}$, slopes of the covariate effects; TBW, patient's body weight (kg); SEX, takes the value 1 for male and 0 for female; g DD, daily dose of vancomycin (mg/day); CLcr, creatinine clearance (ml/min.); LP, length of hosptalization (day); ALB, serum albumin cholesterol (g/l); BIL, total bilirubin $(\mu \mathrm{g} / \mathrm{ll})$; AST, aspartate aminotransferase (IU/l); ALT, alanine aminotransferase (IU/l); CRP, C-reactive protein (mg/l); FIB, fibrinogen (g/l); proBNP, pro-brain natriuretic peptide(pg/ml); COL, FUR, TAZ, NSAIDs, HEP and ACE, co-medication with colistin, furosemid, tazocin, nonsteroidal anti-inflammatory drugs, heparin and angiotensin-converting-enzyme inhibitortakes the value 1 if the patient received co-medication and 0 otherwise

${ }^{* *}$ p-value for the MOF difference between the base and tested models

Table 3. The final model parameter estimates

\begin{tabular}{|l|l|l|l|l|}
\hline Parameter & \multicolumn{2}{|c|}{ NONMEM } & \multicolumn{2}{c|}{ Bootstrap analysis } \\
\hline & Estimate & $\mathbf{9 5 \%}$ CI $^{*}$ & Estimate & $\mathbf{9 5 \% ~ C I}{ }^{* *}$ \\
\hline $\begin{array}{l}\text { Clearance of vancomycin } \\
\text { - CL }(1 / \mathrm{h})\end{array}$ & 0.03 & $0.023-0.035$ & 0.029 & $0.025-0.032$ \\
\hline Central volume of distribution - & 13.2 & $9.84-16.56$ & 13.22 & $9.09-17.35$ \\
\hline Intercompartment clearance Q(1/h) & 0.0001 & $0.00008-0.0001$ & 0.0001 & $0.00009-0.00011$ \\
\hline Daily dose $(\mathrm{mg} /$ day) & 0.000468 & $0.000365-0.000571$ & 0.000464 & $0.000322-0.000507$ \\
\hline Tazacin & 0.675 & $0.5076-0.8424$ & 0.676 & $0.592-0.861$ \\
\hline $\begin{array}{l}\text { Interindividual variance of clearance } \\
-\omega^{2} \text { CL }\end{array}$ & 0.134 & $0.0817-0.1863$ & 0.133 & $0.0801-0.1860$ \\
\hline Residual variance $-\sigma^{2}$ & 0.097 & $0.0527-0.1413$ & 0.096 & $0.0510-0.1410$ \\
\hline
\end{tabular}

${ }^{*}$ (Estimate $\pm 1.96 *($ standard error of the estimate $)$

** $2.5^{\text {th }}$ and $97.5^{\text {th }}$ percentile of the ranked bootstrap parameter estimates 
Figure 1. Predicted vancomycin concentrations versus measured concentrations in the base model (a) and the final model (b), respectively.
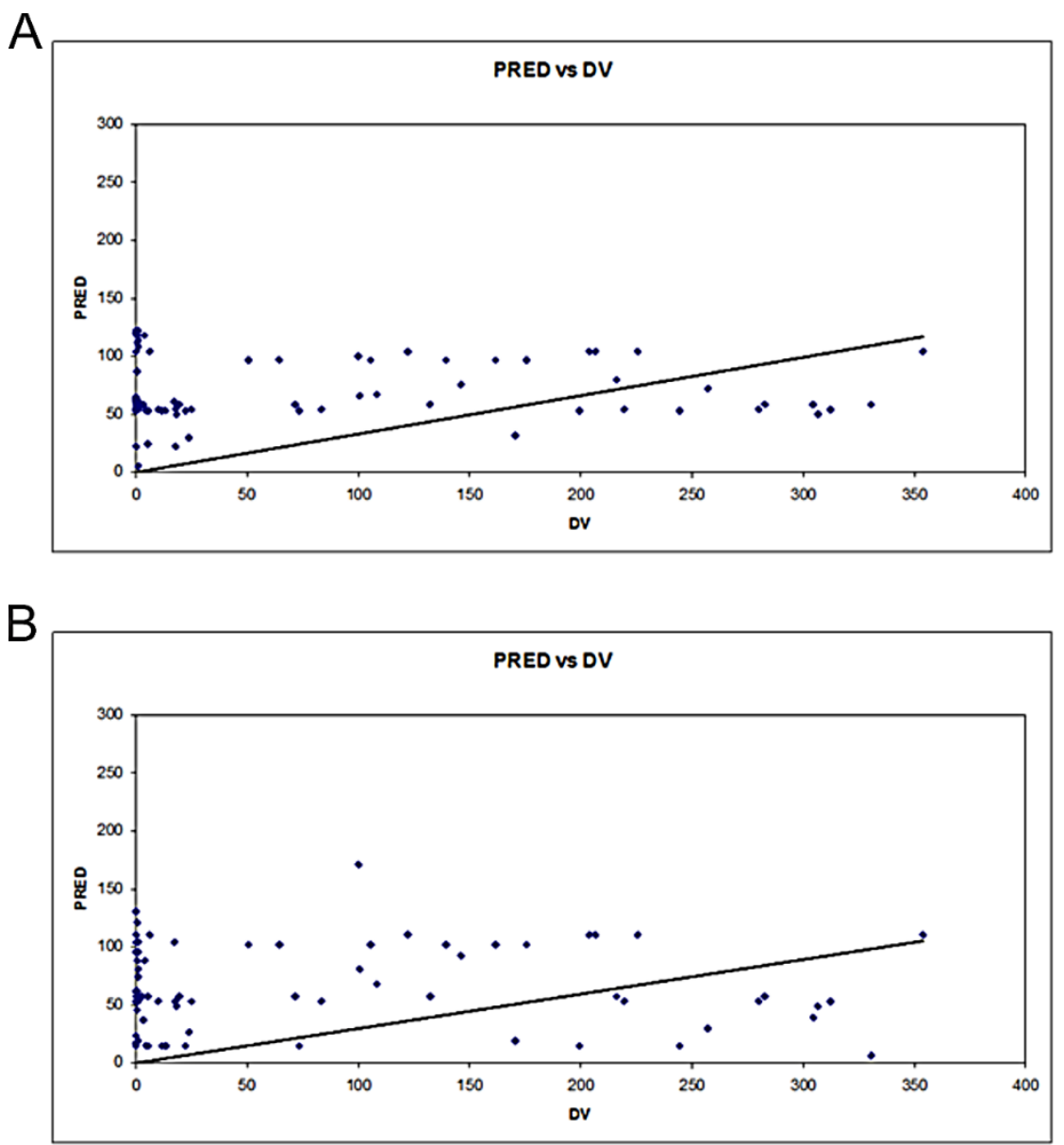

\section{DISCUSSION}

Current study used a population approach to establish the pharmacokinetic parameters of vancomycin in Serbian patients with long bones' fractures, accounting for its large pharmacokinetic variability. Using two-compartment model, typical values of clearance and volume of distribution were calculated, and daily dose of vancomycin and co-medication with piperacillin/tazobactam confirmed as factors with significant influence on clearance of vancomycin.

Higher doses of vancomycin were associated with larger clearance of vancomycin and lower trough serum concentration of vancomycin in our study. Such result is not the first one reported, as Bakke et al. presented similar results, with 70-80 percent of the patients not achieving minimum threshold value of $\geq 15 \mathrm{mg} / \mathrm{l}$ (14). Campassi et al. demonstrated that patients with augmented renal clearance had lower serum concentrations of vancomycin during the first days of therapy despite higher doses, and none of the patients reached therapeutic levels on the first day of the therapy (15). Some authors have proposed that increased loading doses and higher dose frequencies or continuous infusions are necessary in order to achieve higher success rates (16). On the other hand, vancomycin serum concentrations during the first days of therapy also depend on creatinine clearance and low creatinine clearance levels can result in supratherapeutic vancomycin concentrations (17). Hutshala et al. also suggested that more severe impact on renal function might be due to potentially high vancomycin peak concentrations during intermittent infusion. In contrast, constant lower concentrations of vancomycin seem to cause much less renal damage (18). One of the possible explanations of relation between higher doses of vancomycin and its larger clearance could be reduced reabsorption of vancomycin from ultra-filtrate due to tubular toxicity of this drug. Indeed, necrosis of tubular cells was confirmed in histological studies of kidney biopsies taken from the patients who experienced vancomycin-induced renal toxicity, and vancomycin is both secreted and reabsorbed by renal tubular cells $(19,20)$. 
The only medication which significantly affected vancomycin CL in our patients was piperacillin/tazobactam (PT). Piperacillin/tazobactam, similar to the most betalactams, was rarely associated with acute kidney injury and incidence of piperacillin/tazobactam's nephrotoxicity reported in the literature was less than $1 \%$ (21). However, recent meta-analysis that included 14 studies reported that co-administration of vancomycin and piperacillin/tazobactam compared to vancomycin and "any $\beta$-lactam" resulted in the adjusted odds ratio for acute kidney injury in adults of 3.15 (95\% confidence interval [CI], =1.72-5.76) (22). The mechanism by which piperacillin/tazobactam had influence on vancomycin clearance in not well known. It has been thought that vancomycin may cause direct proximal tubular toxicity. The concomitant use of vancomycin and PT has been hypothesized to potentiate acute kidney injury (AKI) via acute interstitial nephritis or decreased secretion of creatinine and vancomycin, but further investigation was considered necessary to confirm those facts (23). By increasing toxic effect of vancomycin on renal tubules, piperacillin may further decrease its reabsorption, leading to increase in vancomycin clearance (24).

Relation between creatinine and vancomycin clearance has been described in various studies (3, 8, 23, 24). We did not observe such relation in our patients. Furthermore, there are studies that supported our observation (27, 28). The existence of a nonrenal mechanism for vancomycin elimination may explain the relatively high values of vancomycin clearances observed in patients with compromised renal function. Hepatic conjugation of vancomycin would seem the most possible nonrenal route of excretion. The vancomycin particle has molecular weight of 1,450 and has essential chemical groups for conjugation with other compounds (27). Some authors reported measurable vancomycin concentrations in the bile after intravenous administration of vancomycin, which is also supporting the idea of extrarenal way of vancomycin elimination (28).

In some earlier pharmacokinetic studies, it was suggested that patients with malignancy had increased clearance of vancomycin (29). Conversely, other authors reported that patients with acute myeloid leukemia had lower clearance of vancomycin (1). It was also noticed that body weight may affect clearance of vancomycin, as increase in weight was related to higher values of both clearance and volume of distribution (3, 30). Finally, some authors showed that furosemide may influence vancomycin clearance, while the others concluded that concomitant drugs had no influence on clearance (9.25).

\section{CONCLUSION}

In conclusion, clearance of vancomycin positively correlated with administered daily dose of that drug and significantly increased by co-medication with piperacillin/tazobactam. This should be taken into account when dosing vancomycin in critically ill patients with fractures of long bones who frequently require high doses of the drug and combination of antibiotic therapy.

\section{ACKNOWLEDGEMENTS}

This study was partially financially supported by Grant No 175007 by the Serbian Ministry of Education, Science and Technological Development. The authors declare that they have no conflict of interest.

\section{REFERENCE}

1. Jarkowski A, Forrest A, Sweeney RP et al. Characterization of vancomycin pharmacokinetics in the adult acute myeloid leukemia population. $\mathrm{J}$ Oncol Pharm Pract. 2012;18(1):91-6.

2. Marsot A, Boulamery A, Bruguerolle B et al. Vancomycin: A Review of Population Pharmacokinetic Analyses. Clin Pharmacokinet. 2012;51(1):1-13.

3. Adane ED, Herald M, Koura F. Pharmacokinetics of Vancomycin in Extremely Obese Patients with Suspected or Confirmed Staphylococcus aureus Infections. Pharmacotherapy. 2015;35(2):127-39.

4. Rodvold KA, Blum RA, Fischer JH et al. Vancomycin pharmacokinetics in patients with various degrees of renal function. Antimicrob Agents Chemother. 1988;6:848-52.

5. Darko W, Medicis JJ, Smith A et al. Mississippi Mud No More: Cost-Effectiveness of Pharmacokinetic Dosage Adjustment of Vancomycin to Prevent Nephrotoxicity. Pharmacotherapy. 2003;23(5):643-50.

6. Lodise TP, Patel N, Lomaestro BM et al. Relationship between Initial Vancomycin Concentration-Time Profile and Nephrotoxicity among Hospitalized Patients. Clin Infect Dis. 2009;49(4):507-14.

7. De Hoog M, Mouton JW, Van den Anker JN. New dosing strategies for antibacterial agents in the neonate. Semin Fetal Neonatal Med. 2005;10:18594.

8. Purwonugroho TA, Chulavatnatol S, Preechagoon Y et al. Population Pharmacokinetics of Vancomycin in Thai Patients. Scientific World Journal. 2012;2012:762649.

9. Lin WW, Wu W, Jiao $\mathrm{Z}$ et al. Population pharmacokinetics of vancomycin in adult Chinese patients with post-craniotomy meningitis and its application in individualised dosage regimens. Eur J Clin Pharmacol. 2016;72(1):29-37.

10. Stockmann C, Hersh AL, Roberts JK et al. Predictive Performance of a Vancomycin Population Pharmacokinetic Model in Neonates. Infect Dis Ther. 2015;4(2):187-98. 
11. Hahn A, Frenck RW Jr, Zou Y et al. Validation of a pediatric population pharmacokinetic model for vancomycin. Ther Drug Monit. 2015;37(3):413-6.

12. Beal SL, Boeckmann AJ, Sheiner LB. NONMEM users guide. Parts I-VIII ICON Development Solutions.

13. Jamsen KM, McLeay SC, Barras MA, et al. Reporting a population pharmacokineticpharmacodynamic study: a journal's perspective. Clin Pharmacokinet. 2014;53(2):111-2.

14. Bakke V, Sporsem H, Von der Lippe E et al. Vancomycin levels are frequently subtherapeutic in critically ill patients: a prospective observational study.Acta Anaesthesiol Scand. 2017;61(6): 627-35.

15. Campassi ML, Gonzalez MC, Masevicius FD et al. Augmented renal clearance in critically ill patients: incidence, associated factors and effects on vancomycin treatment. Rev Bras Ter Intensiva. 2014; 26:13-20.

16. Rybak MJ, Lomaestro BM, Rotschafer JC et al. Vancomycin therapeutic guidelines: a summary of consensus recommendations from the infectious diseases Society of America, the American Society of Health-System Pharmacists, and the Society of Infectious Diseases Pharmacists. Clin Infect Dis. 2009;49: 325-7.

17. Saugel B, Gramm C, Wagner JY et al. Evaluation of a dosing regimen for continuous vancomycin infusion in critically ill patients: an observational study in intensive care unit patients. J Crit Care. 2014; 29:351-5.

18. Hutschala D, Kinstner C, Skhirdladze $\mathrm{K}$ et al. Influence of Vancomycin on Renal Function in Critically Ill Patients after Cardiac Surgery: Continuous versus Intermittent Infusion. Anesthesiology. 2009;111(2): 356-65.

19. Bamgbola O. Review of vancomycin-induced renal toxicity: an update. Ther Adv Endocrinol Metab. 2016;7(3):136-47.

20. Nakamura T, Hashimoto Y, Kokuryo T et al. Effects of fosfomycin and imipenem/cilastatin on nephrotoxicity and renal excretion of vancomycin in rats. Pharmaceutical research.1998;15(5):734-8.
21. Philadelphia, PA: Pfizer; 2012. Zosyn (piperacillin tazobactam) package insert. https://www.pfizer medicalinformation.com/en-us/zosyn/storagehandling.

22. Hammond DA, Smith MN, Li C, et al. Systematic Review and Meta-Analysis of Acute Kidney Injury Associated with Concomitant Vancomycin and Piperacillin/tazobactam. Clin Infect Dis. 2017;64 (5):666-74.

23. Blevins AM, Lashinsky JN, McCammon C et al. Incidence of Acute Kidney Injury in Critically Ill Patients Receiving Vancomycin with Concomitant Piperacillin/Tazobactam, Cefepime, or Merope nem. Antimicrob Agents Chemother. 2019. pii:AAC.02658-18.

24. Kim T, Kandiah S, Patel M et al. Risk factors for kidney injury during vancomycin and piperacillin/ tazobactam administration, including increased odds of injury with combination therapy. BMC research notes. 2015;8(1):579.

25. Medellín-Garibay SE, Ortiz-Martín B, RuedaNaharro A et al. Pharmacokinetics of vancomycin and dosing recommendations for trauma patients. J Antimicrob Chemother. 2016;71(2):471-9.

26. Sanchez JL, Dominguez AR, Lane JR et al. Population pharmacokinetics of vancomycin in adult and geriatric patients: Comparison of eleven approaches. Int J Clin Pharmacol Ther. 2010;48: 525-33.

27. Garaud JJ, Regnier B, Ingleber F et al. Vancomycin pharmacokinetics in critically ill patients. J Antimicrob Chemother. 1984;14, Suppl. D, 53-5.

28. Rotschafer JC, Crossley K, Zaske DE et al. Pharmacokinetics of Vancomycin: Observations in 28 Patients and Dosage Recommendations. Antimicrob Agents Chemother. 1982;22(3):391-4.

29. Al-Kofide H, Zaghloul I, Al-Naim L Pharmacokinetics of vancomycin in adult cancer patients. J Oncol Pharm Pract. 2010;16(4):245-50.

30. Moore JN, Healy JR, Thoma BN et al. A Population Pharmacokinetic Model for Vancomycin in Adult Patients Receiving Extracorporeal Membrane. CPT Pharmacometrics Syst Pharmacol. 2016;5(9): 495-502. 